\title{
Nutrient Management in Finger Millet (Eleusine coracana L. Gaertn) in India
}

\author{
Sagar Maitra*, M. Devender Reddy and S.P. Nanda
}

M.S. Swaminathan School of Agriculture, Centurion University of Technology and Management, Paralakhemundi-761211, India *Corresponding author: sagar.maitra@cutm.ac.in (ORCID ID: 0000-0001-8210-1531)

Paper No. 811

Received: 27-09-2019

Revised: 22-01-2020

Accepted: 28-02-2020

\begin{abstract}
In India finger millet is mostly cultivated in resource poor soils of tropics and sub-tropics. Synchronizing nutrient supply with crop demand is essential to maximize yield and fertilizer use efficiency. It has been found that incorporation of $\mathrm{N}$ fertilizer during seeding stage increased yield as compared to broadcasting of fertilizer. The continuous application of inorganic $\mathrm{N}$ fertilizer reduced the soil organic carbon level. The foliar application of $2 \%$ urea produced higher grain and straw yield. Application of fertilizer P @ 125\% recommended dose of phosphorus (RDP) with recommended N, K and FYM in different fertility soils recorded higher grain and straw yield. Nutrient management for targeting production and sustainability, integrated nutrient management (INM) will be the most suitable option. Application of $100 \%$ NPK along with FYM @ $10 \mathrm{t} \mathrm{ha}^{-1}$ recorded significantly higher grain and straw yield and enriched the soil organic carbon. Application of farmyard manure (FYM) alone or in a combination with chemical fertilizers contributed to higher amounts of carbon inputs and build up a higher soil organic carbon pool in rain fed groundnut-finger millet rotation in alfisol of semi-arid region. Cropping system approach either sequential or intercropping with legume was found beneficial. Treating seeds with Azospirillum brasilense ( $\mathrm{N}$ fixing bacterium) and Aspergillus awamori (P Solubilizing fungus) @ $25 \mathrm{~g} \mathrm{~kg}^{-1}$ seed of finger millet found to be beneficial. Soil test crop response (STCR) need to be considered for supplying nutrients more precisely with a target yield output. In the present paper, the available literature on different options of nutrients application to finger millet for sustainable productivity is reviewed.

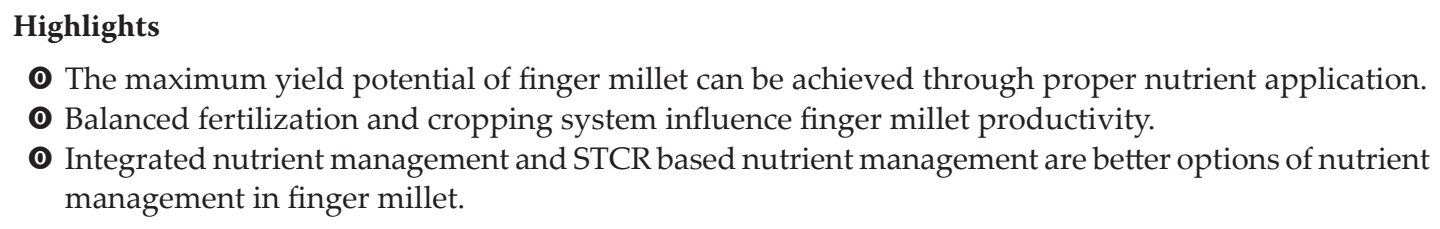

Keywords: Finger millet, integrated nutrient management, cropping system, productivity, sustainability

Millets exhibit unique characteristics amongst cereals. These can grow well under dry and aberrant weather conditions, can cope with relatively poor soils and require comparatively less external inputs than major cereals, namely rice, wheat and maize. Millets are a staple food with superior nutritional qualities and used both as food and fodder. In addition, millets sequestrate carbon, thereby adding to $\mathrm{CO}_{2}$ abatement opportunities, contribute to enhanced agro-biodiversity by their rich varietal diversity, ecologically beneficial (Brahmachari et al.
2018), allow for mutually beneficial intercropping with other important crops (Maitra et al. 2000). Under the changing scenario of global warming and climate change, cultivation of ecologically sound and hardy millets may be a wise alternative for optimum output with food and nutritional security. India is the largest producer of various kinds of millets. Out of the total minor millets produced, finger millet (Eleusine coracana L. Gaertn) accounts for about $85 \%$ of production in India (Sakamma et al. 2018) and it has the pride of place in having highest 
productivity among small millets. In India, finger millet is cultivated mainly in the states of Karnataka, Tamil Nadu, Andhra Pradesh, Orissa, Jharkhand, Uttaranchal, Maharashtra, and Gujarat occupying an area of 1.27 million hectares with a production of 2.61 million tonnes and average productivity of $1489 \mathrm{~kg} \mathrm{ha}^{-1}$ (Agriculture Statistics at a Glance 2017). The crop has wide adaptation with easy cultivation, free from major pests and diseases and drought tolerance which have made this crop an automatic choice in dry farming system. Further, in the lands where finger millet crop is cultivated, no other profit making crop can be grown with reasonable harvest (AICSMIP 2013).

Finger millet is known as a low fertilizer input crop by the small farmers who live on subsistence farming. Under low nutrient input conditions, the crop expresses poor yields. In India, finger millet is mostly cultivated in resource poor soils of tropics and sub-tropics. But there are improved varieties of finger millet which respond to added nutrients. Nutrient management should be done targeting production sustainability and integrated nutrient management (INM) is the most suitable option in this regard. Further, production sustainability can be achieved through use of all possible sources of nutrients to match the soil nutrient availability with crop demand (spatially and temporally). The major advantages of INM are increase in yield, water use efficiency, grain quality, economic return, and sustainability. The site specific nutrient management (SSNM) as well as soil test crop response (STCR) adds new dimensions of nutrient management of crops. In the present article, the available scientific information in India was collected and presented in the following pages on different options of nutrient management, sources, levels and methods of application for sustaining productivity of finger millet.

\section{Nutrient management options}

Like in other crops, improved varieties of finger millet respond well to added nutrients as the crop is generally cultivated under poor soil conditions. Compared to major cereals, the recommendations available for nutrient management in finger millet is meager under different agro-climatic conditions. There is enough scope to address the issues related to nutrient management in finger millet.
Researchers and technocrats advocate in favour of integrated nutrient management (INM) for different crops and cropping systems. The INM shows the path of agricultural sustainability as it provides enough scope of soil fertility enhancement including enrichment of soil microbial activity. The major objectives of INM are enhancement of crop productivity by providing essential nutrients and increase in resource use efficiency. Recent development in research in precision agriculture suggests soil test crop response (STCR) approach in different crops for targeting of nutrient inputs and yield output. On the basis of published work on nutrient management of finger millet, an initiative has been taken to bring information together on the options and methods of nutrient management under different situations to achieve production sustainability.

\section{Chemical Fertilizers}

\section{Nitrogen}

\section{Levels of Nitrogen}

Application of the correct level of $\mathrm{N}$ fertilizer is important to obtain optimum yield of finger millet and thus make its cultivation profitable. Many of the soils where finger millet is grown are deficient in $\mathrm{N}$. Earlier research work revealed that finger millet responded to graded levels of $\mathrm{N}$ and summary of some of the research findings are presented in table 1.

\section{Time of application}

Time of $\mathrm{N}$ application is important in finger millet production. Hegde and Gowda (1986) claimed that incorporation of $\mathrm{N}$ fertilizer during seeding stage increased yield by $30 \%$ compared to fertilizer broadcasting as basal dose. Synchronizing N supply with crop $\mathrm{N}$ demand is essential to maximize yield and $\mathrm{N}$ use efficiency. Further they reported that on sandy loam soils, application of $\mathrm{N}$ at $50 \mathrm{~kg} \mathrm{ha}^{-1}$ produced lower grain yield when applied only at planting, whereas the yield increased when the application was done in two splits (at planting and 25-30 days after planting). Chavan et al. (2018) concluded that application of $\mathrm{N}$ in 3 splits at transplanting $(\mathrm{T}), 30$ and 60 days after transplanting (DAT) resulted in more dry matter production, 
Table 1: Findings of levels of on finger millet in India

\begin{tabular}{|c|c|c|}
\hline Location, soil properties, growing situation & Findings & Source \\
\hline $\begin{array}{l}\text { Typical Ultisols, rainfed upland of red and lateritic belt (West } \\
\text { Bengal), sandy clay loam, acidic soil ( } \mathrm{pH} \text { 5.2) with } 0.32 \% \\
\text { Organic C, } 122 \mathrm{~kg} \text { ha- }{ }^{-1} \text { available N, } 13.7 \mathrm{~kg} \mathrm{ha}^{-1} \mathrm{P} \text { and } 322 \mathrm{~kg} \\
\text { ha }^{-1} \mathrm{~K} \text {. }\end{array}$ & $\begin{array}{l}\text { Application of } 60 \mathrm{~kg} \mathrm{~N}^{-1} \text { produced } \\
\text { significantly more grain yield than } 40 \mathrm{~kg} \\
\mathrm{~N}^{-1} \text { and control. }\end{array}$ & Roy et al. (1996) \\
\hline $\begin{array}{l}\text { Lateritic soil (Ultisols) of West Bengal, sandy loam, acidic soil } \\
\text { (pH 5.8), organic C 0.42\%, available N } 248.6 \mathrm{~kg} \mathrm{ha}^{-1}, \mathrm{P} 17.3 \mathrm{~kg} \\
\text { ha }^{-1} \text { and } \mathrm{K} \mathrm{kg} \mathrm{ha}^{-1} 193.2 \text {; rainfed kharif crop grown in uplands. }\end{array}$ & $\begin{array}{l}\text { Application of } 60 \mathrm{~kg} \mathrm{~N} \mathrm{ha}^{-1} \text { produced } \\
\text { significantly more grain yield }(1183 \mathrm{~kg} \\
\left.\mathrm{ha}^{-1}\right) \text { than } 30 \mathrm{~kg} \mathrm{~N} \mathrm{ha}^{-1}\left(1072 \mathrm{~kg} \mathrm{ha}^{-1}\right) \text { and } \\
\text { control }\left(827 \mathrm{~kg} \mathrm{ha}^{-1}\right) \text {. }\end{array}$ & Roy et al. (2002) \\
\hline $\begin{array}{l}\text { Silty clay loam of Tehri Garhwal (Uttarakhand) with } \mathrm{pH} \text { of 5.8, } \\
\text { low in available nitrogen }\left(180 \mathrm{~kg} \mathrm{ha}^{-1}\right) \text {, medium in available } \\
\text { phosphorous }\left(14 \mathrm{~kg} \mathrm{ha}^{-1}\right) \text { and available potassium }\left(389 \mathrm{~kg} \mathrm{ha}^{-1}\right) \text {; } \\
\text { rainfed, kharif crop grown in hilly uplands. }\end{array}$ & $\begin{array}{l}\text { Application of } 60 \mathrm{~kg} \mathrm{Nha}^{-1} \text { produced } \\
\text { significantly more grain yield }(2291 \mathrm{~kg} \\
\left.\mathrm{ha}^{-1}\right) \text { than } 40 \mathrm{~kg} \mathrm{~N} \mathrm{ha}^{-1}\left(2063 \mathrm{~kg} \mathrm{ha}^{-1}\right), 20 \mathrm{~kg} \\
\mathrm{~N} \mathrm{ha}^{-1}\left(1661 \mathrm{~kg} \mathrm{ha}^{-1}\right) \text { and control }(1385 \mathrm{~kg} \\
\left.\mathrm{ha}^{-1}\right) \text {. }\end{array}$ & Yadav et al. (2010) \\
\hline
\end{tabular}

efficient partitioning of assimilate and higher yield than 2 splits ( $\mathrm{T}$ and $30 \mathrm{DAT}$ ) and 4 splits (T, 20, 40 and 60 DAT) at Ratnagiri, Maharashtra. On the other hand, Prabhakar et al. (2017) in direct seeded crop suggested applying $50 \%$ of recommended $\mathrm{N}$ at sowing and the remaining $50 \%$ in two equal splits at 25-30 and 40-45 days after sowing in the areas of good rainfall; but in areas of uncertain rainfall, $50 \%$ at sowing and the remaining $50 \%$ around 35 days after sowing was recommended. Based on a long-term field experiment with finger millet, Hemalatha and Chellamuthu (2013) found that continuous application of inorganic $\mathrm{N}$ fertilizer alone reduced the soil organic carbon level. On the other hand, foliar application of nitrogenous fertilizer ( $2 \%$ urea) expressed a positive impact on productivity of finger millet (Reddy et al., 2018) in a field experiment conducted at Kolhapur, Maharashtra during kharif season.

\section{Phosphorus and Potassium}

One of the main problems faced by the farmers is inherent low soil $\mathrm{P}$ in areas where finger millet is commonly grown. $\mathrm{P}$ has distinct role in yield improvement of finger millet. Chandrakala et al. (2017) concluded that application of fertilizer P @ $125 \%$ recommended dose of phosphorus (RDP) with recommended $\mathrm{N}, \mathrm{K}$ and FYM in very low, low and medium fertility soils recorded higher grain and straw yield of finger millet. Application of $100 \%$ or $75 \%$ RDP with recommended N, K and FYM were optimum though there was an increase in yield at higher rate of $\mathrm{P}$ application in high $\mathrm{P}$ fertility soils. The phosphorus use efficiency (PUE) was higher at lower levels of P application. Sundaresh and Basavaraja (2017) reported higher grain yield with application of 100 per cent RDN, 150 per cent RDP and 125 per cent recommended dose of potassium (RDK) along with FYM at $10 \mathrm{t} \mathrm{ha}^{-1}$ (100:75:62.5 kg NPK ha-1) in Alfisols of Ramanagara district of Karnataka having sandy loam soil with $\mathrm{pH}$ 6.3, deficient in available phosphorus (12.8 $\left.\mathrm{kg} \mathrm{ha}^{-1}\right)$ and potassium (108.7 $\mathrm{kg} \mathrm{ha}^{-1}$ ), under protective irrigation. Ramachandrappa et al. (2013) reported significantly higher grain yield of finger millet with recommended $\mathrm{N}, \mathrm{P}_{2} \mathrm{O}_{5}+150$ per cent of recommended $\mathrm{K}_{2} \mathrm{O}$ applied at planting compared to recommended NPK at UAS, Bangalore on Alfisols, sandy-clay-loam in texture with $\mathrm{pH} 5.70, \mathrm{EC} 0.07 \mathrm{dS}$ $\mathrm{m}^{-1}$ and $0.46 \%$ organic carbon, available $\mathrm{N}, \mathrm{P}$ and $\mathrm{K}$ status was 159, 60 and $110 \mathrm{~kg} \mathrm{ha}^{-1}$, respectively. They further concluded that application of recommended $\mathrm{N}, \mathrm{P}_{2} \mathrm{O}_{5}+150$ per cent of recommended $\mathrm{K}_{2} \mathrm{O}$ as basal dose (50: 40: $37.5 \mathrm{~kg} \mathrm{NPK} \mathrm{ha}{ }^{-1}$ ) is required for getting higher grain and straw yields and to achieve higher sustainability yield index (SYI), B: C ratio, potassium use efficiency (KUE) and apparent potassium recovery (APR) in rainfed areas.

\section{Nitrogen, phosphorus and potassium}

Nitrogen, phosphorus and potassium are the primary macro nutrients mainly responsible for productivity of crops. In general, fertilizer recommendations consist of different levels of macro-nutrients for higher yields. The results of experiments conducted with macro-nutrients are presented below (Table 2). 
Table 2: Findings of combined application of chemical N, P and $\mathrm{K}$ on finger millet in India

\begin{tabular}{|c|c|c|}
\hline Location, soil properties, growing situation & Findings & Source \\
\hline $\begin{array}{l}\text { Zonal Agricultural Research station, Kolhapur } \\
\text { during kharif in sub- mountain zone in sandy } \\
\text { clay loam textured soil with low in available } \\
\text { phosphorus and moderately high in available } \\
\text { nitrogen and potash, neutral in soil reaction }\end{array}$ & $\begin{array}{l}\text { Application of RDF through briquettes }(60: 30: 00 \mathrm{~kg} \\
\text { NPK ha-1) is an optimum dose and advisable for } \\
\text { obtaining the maximum grain }\left(2520 \mathrm{~kg} \mathrm{ha}^{-1}\right) \text { and } \\
\left.\text { straw yield ( } 3272 \mathrm{~kg} \mathrm{ha}^{-1}\right) \text { as against absolute control } \\
\text { treatment with grain }\left(1010 \mathrm{~kg} \mathrm{ha}^{-1}\right) \text { and straw yield } \\
\left(1270 \mathrm{~kg} \mathrm{ha}^{-1}\right) \text {. }\end{array}$ & Patil et al. (2015) \\
\hline $\begin{array}{l}\text { Brown forest soil (Odisha), sandy loam in texture, } \\
\text { pH 6.5, medium in organic carbon }(0.50 \%) \text {, low } \\
\text { in available nitrogen }\left(104 \mathrm{~kg} \mathrm{ha}^{-1}\right) \text {, medium in } \\
\text { available phosphorus }\left(23 \mathrm{~kg} \mathrm{ha}^{-1}\right) \text { and medium in } \\
\text { available potassium }\left(196 \mathrm{~kg} \mathrm{ha}^{-1}\right) ; \text { kharif season in } \\
\text { rainfed uplands. }\end{array}$ & $\begin{array}{l}\text { The highest grain yield was achieved from the } \\
\text { treatment with } 100 \% \mathrm{RDF} @ 40-20-20 \mathrm{~kg} \mathrm{~N}, \mathrm{P}_{2} \mathrm{O}_{5} \text { and } \\
\mathrm{K}_{2} \mathrm{O} \text { ha-1 }\left(1412 \mathrm{~kg} \mathrm{ha}^{-1} \text { ) compared to control (without }\right. \\
\text { any nutrient) with grain yield of } 637 \mathrm{~kg} \mathrm{ha}^{-1} \text {. }\end{array}$ & Harika et al. (2019) \\
\hline $\begin{array}{l}\text { Experiment was carried out at Paralakhemundi } \\
\text { (Odisha) in sandy loam soil with } \mathrm{pH} 6.5 \text {, during } \\
\text { summer season. }\end{array}$ & $\begin{array}{l}\text { There was improvement of plant height and yield } \\
\text { attributes with } 90 \mathrm{~kg} \mathrm{~N} \mathrm{ha}^{-1} \text { than lower levels }(0,30 \\
\left.\text { and } 60 \mathrm{~kg} \mathrm{ha}^{-1}\right) \text {. Increase in phosphorus level from } 20 \\
\text { to } 40 \mathrm{~kg} \mathrm{ha}^{-1} \text { enhanced productivity. A combination of } \\
90 \mathrm{~kg} \mathrm{~N} \text { and } 40 \mathrm{~kg} \mathrm{P} \mathrm{ha}^{-1} \text { registered the highest grain } \\
\text { and straw yield (1054 and } 4369 \mathrm{~kg} \mathrm{ha}^{-1} \text { respectively). }\end{array}$ & $\begin{array}{l}\text { Vamshi Krishna et } \\
\text { al. (2019) }\end{array}$ \\
\hline
\end{tabular}

The field experiment conducted during kharif at Vizianagaram, Andhra Pradesh on sandy loam soil having low in organic carbon, available nitrogen, high in available phosphorus and medium in available potassium indicated that significantly higher grain and straw yields of finger millet with $150 \% \mathrm{RDF}+\mathrm{ZnSO}_{4} 0.5 \%$ foliar spray $+\mathrm{FeSO}_{4}$ $0.2 \%$ foliar spray (Sandhya Rani et al. 2017a). The highest available soil macronutrients and uptake of plant macronutrients were also found in the same treatment. Whereas, the highest available $\mathrm{Zn}$ in the soil was found in the treatment $150 \% \mathrm{RDF}+\mathrm{ZnSO}_{4}$ soil application $+\mathrm{FeSO}_{4} 0.2 \%$ foliar spray (3.32ppm), and the highest available Fe in the treatment $150 \%$ $\mathrm{RDF}+\mathrm{FeSO}_{4}$ 0.2\% foliar spray (17.63ppm). Field experiments conducted at Zonal Agricultural Research Station, Kolhapur (Maharashtra) on Entisol, during kharif seasons of 2014 to 2016 showed yield enhancement of finger millet with foliar spray of 19-19-19 @ 2\% over the recommended dose of fertilizer (Bulbule et al. 2018).

\section{Organic manures in nutrient management}

Organic manures play important role by supplying variety of nutrients and release them slowly, improve soil fertility and enhance efficiency of added chemical inputs. There are different kinds of organic manures and with positive impact on productivity enhancement of finger millet. Adequate application of FYM, 7.5 to $10 \mathrm{t} \mathrm{ha}^{-1}$ helps in better development of root growth (Prabhakar et al. 2017). Research trials showed increased growth and productivity with the application of organic manures alone or in combination with other sources of nutrients. Rangaswamy (1973) noted that FYM increased the grain yield of early and short duration cultivars by 9.5 and $3.5 \%$, respectively. During present days, the organic agriculture is becoming popular with a steady growth in terms of area expansion and increase in production of agricultural crops. General acceptance of organic agriculture is not only due to greater demand for pollution free food but also due to natural advantage in supporting the sustainability in agriculture. Like other staple foods, finger millet has also drawn the attention of scientists and trials have been conducted on organic production of finger millet. Gawade et al. (2013) observed that differnet organic manures, namely poultry manure, farm yard manure and vermicompost applied @ 1.32,3.0 and $1.5 \mathrm{t} \mathrm{ha}^{-1}$ equivalent to $20 \mathrm{~kg} \mathrm{~N}^{-1}$ registered yield of finger millet of 2211, 1740 and $1942 \mathrm{~kg} \mathrm{ha}^{-1}$ respectively as against $1536 \mathrm{~kg} \mathrm{ha}^{-1}$ in unfertilized control. Basavaraj Naik (2017) in an experiment on finger millet at Agricultural and Horticultural Research Station, Bavikere, University of Agricultural and Horticultural Sciences, Shivamogga, concluded that application of FYM at $10 \mathrm{t} \mathrm{ha}^{-1}+$ biodigester liquid manure equivalent (two splits) at $75 \mathrm{~kg} \mathrm{~N}$ $\mathrm{ha}^{-1}$ recorded higher growth and yield attributing parameters and yield. 


\section{Biofertilizers in nutrient management}

Bio-fertilizers are living and latent cells of microorganisms which under favourable conditions multiply rapidly and supply, mobilize and solubilize plant nutrients. Therefore, integration of these with organic manures and chemical fertilizers adds value for sustaining crop productivity by creating a healthy ecosystem. Treating seeds with Azospirillum brasilense ( $\mathrm{N}$ fixing bacterium) and Aspergillus awamori (P Solubilizing fungus) @ $25 \mathrm{~g} \mathrm{~kg}^{-1}$ seed of finger millet is beneficial (Prabhakar et al. 2017). Maitra et al. (1997) mentioned that application of biofertilizer (Azospirillum) resulted in higher productivity (890 $\left.\mathrm{kg} \mathrm{ha}^{-1}\right)$ as against control (711 kg ha-1). Ramakrishnan and Bhuvaneswari (2014) reported that, single inoculation of Arbuscular Mycorrhizal (AM) fungi (Glomus mossease) and combined inoculation of AM fungi with Azospirillium brasilense or PSB found to moderately increase growth. However, triple inoculation of AM fungi, Azospirillium brasilense and PSB was found to result highest growth parameters. In general, biofertilizers perform well in combination with organic manures and inorganic fertilizers. Harika et al. (2019) reported that application of FYM (8 t $\left.\mathrm{ha}^{-1}\right)+$ Azospirillum $\left(5 \mathrm{~kg} \mathrm{ha}^{-1}\right)$ recorded more yield $\left(701 \mathrm{~kg} \mathrm{ha}^{-1}\right)$ than unfertilized control $\left(637 \mathrm{~kg} \mathrm{ha}^{-1}\right)$ in brown forest soil of south Odisha. Kejia et al. (2019) observed that biofertilizers performed well in combination with chemical phosphorus fertilization. The authors mentioned that application of $100 \%$ RDP ( $40 \mathrm{~kg} \mathrm{ha}^{-1}$ ) + PSB @ 750 ml ha-1 + VAM @ 12.5 $\mathrm{kg} \mathrm{ha}^{-1}$ produced higher dry matter production, yield attributes (number of tillers $\mathrm{m}^{-2}$, number of ear heads $\mathrm{m}^{-2}$, number of fingers ear head ${ }^{-1}$ and length of ear head), grain yield (4328 $\left.\mathrm{kg} \mathrm{ha}^{-1}\right)$ and stover yield, grain quality parameters (protein, carbohydrate content) in finger millet whereas the treatment without any chemical fertilizer registered significantly less yield (3692 $\left.\mathrm{kg} \mathrm{ha}^{-1}\right)$.

\section{Integrated Nutrient Management (INM)}

INM is the application of nutrients in crops from all possible sources in suitable and compatible manner to enrich soil health targeting sustainability. In INM, plant nutrients are supplied through organic manures, biofertilizers and chemicals to meet the requirement of crops. Organic manures are known not only to improve physical and chemical properties but to create congenial environment for soil micro-organisms and enhance efficiency of chemical fertilizers. Some of the research evidences of productivity enhancement of finger millet through INM are presented in the Table 3.

Arulmozhiselvan et al. (2013) conducted long term fertilizer experiment since 1972 under maizefinger millet cropping sequence and studied effect of continuous fertilization and manuring on productivity, soil health and nutrient removal by the crop in the year 2011 at Tamil Nadu Agricultural University. Application of $100 \%$ NPK along with FYM@ 10 t ha $^{-1}$ recorded significantly higher grain (2571 kg ha-1) and straw yield of finger millet, higher NPK uptake and enrichment of soil organic carbon. Long term experiment (1992 to 2011) carried out at UAS, Bangalore, Karnataka on finger millet indicated that the largest soil quality index (SQI) of 7.29 was noted with FYM $10 \mathrm{t} \mathrm{ha}^{-1}+100 \%$ NPK, however the lowest value of 3.70 observed with control. Application of $10 \mathrm{tha}^{-1}$ FYM together with NPK (50:50:25 kg ha-1) sustained a mean yield of $3884 \mathrm{~kg} \mathrm{ha}^{-1}$. The key indicators which contributed to the soil quality index (SQI) under rotation were organic C; potentially available $\mathrm{N}$; extractable $\mathrm{P}, \mathrm{K}$ and $\mathrm{S}$; exchangeable $\mathrm{Ca}$ and $\mathrm{Mg}$; dehydrogenase activity and microbial biomass $\mathrm{C}$ and $\mathrm{N}$ (Sathish et al. 2016). Further, application of $10 \mathrm{t} \mathrm{ha}^{-1}$ FYM together with $100 \%$ NPK (50:50:25 $\mathrm{kg} \mathrm{ha}^{-1}$ ) sustained a mean finger millet yield of $3884 \mathrm{~kg} \mathrm{ha}^{-1}$ indicating that integrated nutrient management assured sustained productivity along with improvement of soil quality.

\section{Cropping system and nutrient management}

Finger millet can be accommodated in different cropping systems and it impacts of the nutrient management in the system. Pallavi et al. (2016 a, b) reported from Rajendranagar, Hyderabad, in agro-forestry system under Melia azedarach based agri-silvi system that integrated use of 75\% RDN $+25 \% \mathrm{~N}$ through poultry manure and $100 \% \mathrm{RDF}$ resulted higher yield of finger millet and it was on par with sole crop in red sandy loam soils under rainfed conditions.

Cereal-legume combination in cropping system is considered an ideal system for sustainable production. Long-term nutrient management and cropping systems experiments are needed for finger 
Table 3: Findings of INM studies on finger millet in India

Location, soil properties, growing situation
Kharif crop at Coimbatore (Tamil Nadu) on
clay loam soil with pH 8.3, EC $0.38 \mathrm{dS} \mathrm{m}{ }^{-1}$,
available N $166 \mathrm{~kg} \mathrm{ha}^{-1}$, available P $12.3 \mathrm{~kg}$
ha $^{-1}$ and available K $243 \mathrm{~kg} \mathrm{ha}^{-1}$.

Irrigated kharif crop at Hebbal, UAS, Bangalore (Karnataka), red sandy loam soil with low in organic carbon (0.34\%), pH 6.0, available N $172.1 \mathrm{~kg} \mathrm{ha}^{-1}$, available P $31.3 \mathrm{~kg}$ ha $^{-1}$ and available K (172.0 kg ha-1).

Kharif crop at Ratnagiri (Maharashtra) on terraced uplands in south Konkan conditions

Long term experiment conducted in Inceptisols (taxonomically grouped under Vertic Ustropept), sandy clay loam soil of Coimbatore (Tamil Nadu).

Kharif finger millet at Ranchi (Jharkhand), sandy loam soil, organic C $4.23 \mathrm{~g} \mathrm{~kg}^{-1}$, acidic ( $\mathrm{pH} 5.4)$, low in available nitrogen $(232.47 \mathrm{~kg}$ $\left.\mathrm{ha}^{-1}\right)$, medium in available phosphorus (14.30 $\mathrm{kg} / \mathrm{ha})$ and potassium (131.84 $\left.\mathrm{kg} \mathrm{ha}^{-1}\right)$.

\section{Findings}

Application of recommended N (50\% through FYM and $50 \%$ through urea) and $50 \%$ of recommended $\mathrm{P}$ and $\mathrm{K}$ along with seed inoculation of biofertilizers (Azospirillum and Aspergillus each @ $25 \mathrm{~g} \mathrm{kg-1} \mathrm{seed}$ produced higher values of yield attributes with increased benefit : cost ratio over farmers' practice by $56 \%$.

Integrated use of recommended NPK and FYM treatment recorded significantly higher grain $(3086 \mathrm{~kg}$ $\left.\mathrm{ha}^{-1}\right)$ as compared to recommended chemical NPK alone $\left(2946 \mathrm{~kg} \mathrm{ha}^{-1}\right)$.

Application of FYM @ 5t ha-1 + RDF (60-30-00 kg NPK ha ${ }^{-1}$ ) recorded significantly higher grain yield $2227 \mathrm{~kg} \mathrm{ha}^{-1}$ and it was at par with the treatment with application of FYM @ 5t ha ${ }^{-1}+75 \%$ RDF + biofertilizers (Azospirillum and PSB) seed inoculation @25 g each in $\mathrm{kg}^{-1}$ seed (2075 kg ha-1).

Application of $100 \%$ NPK along with FYM @ $10 \mathrm{t} \mathrm{ha}^{-1}$ recorded significantly higher grain $\left(2571 \mathrm{~kg} \mathrm{ha}^{-1}\right)$ and straw (5237 kg ha-1) yield than control (1874 kg ha-1 and $4035 \mathrm{~kg} \mathrm{ha}^{-1}$ respectively).

Grain (3337 kg ha-1) and straw yield (6983 kg ha-1) were higher with application FYM (10 t ha-1) + Biofertilizers (Azospirillum brasilense + Bacillus spp. + Psuedomonas flurosence@ $20 \mathrm{~g} \mathrm{~kg}^{-1}$ seed each) + ZnSO4 (12.5 kg ha-1) $+\operatorname{Borax}\left(\mathrm{kg} \mathrm{ha}^{-1}\right)+100 \%$ RDF (50:30:25) against 100\% RDF (grain and straw yield of 2391 and $4879 \mathrm{~kg} \mathrm{ha}^{-1}$ respectively).

\section{Source}

Ramamoorthy and

Lourduraj (2002)

Kumara et al. (2007)

Ahiwale et al. (2011)

Ahiwale et al. (2011)

Arulmozhiselvan et al. (2013)

Roy et al. (2018)



millet based cropping system to assess changes in soil quality, organic carbon pool, and agronomic sustainability. Srinivasa Rao (2012) reported application of farmyard manure (FYM) alone or in a combination with chemical fertilizers contributed to higher amounts of $C$ inputs and subsequently to build up a higher SOC pool on the basis of a 13-year-old soil fertility management experiment of rainfed groundnut- finger millet rotation in semi-arid alfisol. Pavankumar et al. (2016) observed significantly higher grain yield, net returns and B:C ratio over mono cropping of finger millet in finger millet-groundnut rotation.

In finger millet + legume intercropping system, generally beneficial effects are observed in terms of greater utilization of land resources, total crop yield and higher monetary returns. Maitra et al. (2000) reported reduced grain and straw yield of finger millet when intercropped with legumes compared with the pure stand of finger millet in a replacement series of 4:1 ratio of finger millet : legumes and such reduction was due to decrease in plant stand compared to that of sole cropping of finger millet. But, the combined yield of finger millet and legumes was much higher in different intercropping systems like finger millet + redgram, finger millet + groundnut and finger millet + soybean and these intercrop combinations registered higher land equivalent ratio and monetary advantage over sole cropping of finger millet in red and lateritic belt of West Bengal. Further, all intercropping combinations resulted in more productivity with 60-13.3-25 kg N-P-K ha-1 which was significantly superior to its lower level (30-6.7-12.5 kg N-P-K ha-1) and absolute control when nutrients were supplied through only chemical sources. Application of organic manures also showed positive impact on productivity of finger millet-based intercropping system. Jagadeesha et al. (2010) reported application of either sewage sludge or poultry manure compost produced significantly higher grain and straw yield 
of finger millet and red gram grain and stalk yield. The study clearly revealed that sewage sludge and poultry manure compost application at equivalent recommended nitrogen level could be successfully used for finger millet and redgram intercropping system to substitute chemical fertilizers.

\section{Soil test crop response (STCR) approach}

Efficient crop fertilization programme to meet the crop nutrient needs is essential for sustainable agriculture. Among the various scientific methods of fertilizer recommendations, which incorporate nutrient requirement of the crop, contribution of nutrients from soil, manures, fertilizers and fixing yield-targets is only the Soil Test Crop Response (STCR) approach (Regar and Singh 2014). Fertilizer recommendation based on yield target was first initiated by Troug (1960), which later modified by Ramomoorthy et al. (1967) to suit the Indian condition. It provides a scientific basis for balanced fertilization and balance between applied nutrients and soil available nutrients (Choudhary et al. 2019). STCR approach is aiming at obtaining a basis for precise quantitative adjustment of fertilizer doses under varying soil test values and response conditions of the farmers and for targeted levels of crop production. Studies on nutrient management in finger millet with STCR approach are not sufficient; however, Sandhya Rani et al. (2017b) reported improved growth characters, yield contributing characters, grain and straw yields and soil available nutrients in the treatment 200\% RDN + 100\% RDP+ $100 \%$ RDK $+25 \%$ RDZn $+25 \%$ RDS $+25 \%$ RDB integrated with $5 \mathrm{t} \mathrm{ha}^{-1}$ FYM which was on par with the treatment in which fertilizers were applied based on STCR equation for a targeted yield of $4 \mathrm{t}$ ha $^{-1}$ in soils whose nitrogen levels are low (below $140 \mathrm{~kg} \mathrm{ha}^{-1}$ ), high phosphorus levels and medium potassium levels at Vizianagaram, Andhra Pradesh. Further, they concluded that in soils with low $\mathrm{N}$ (less than $140 \mathrm{~kg} \mathrm{ha}^{-1}$ ) increase in the $\mathrm{N}$ dose up to $200 \%$ along with micronutrients could give yields on par with the nutrient supply using STCR approach and the targeted yield in finger millet could be achieved with integrated nutrient supply using STCR approach. In another experiment conducted by Saraswathi et al. (2018) on alfisols of Karnataka on precision nutrient management in finger millet, higher grain yield was reported (3238 $\left.\mathrm{kg} \mathrm{ha}^{-1}\right)$ with the application of STCR based NPK and compost $10 \mathrm{t} \mathrm{ha}^{-1}$ for targeted yield of $4 \mathrm{t} \mathrm{ha}^{-1}$ over that of control (2385.7 $\left.\mathrm{kg} \mathrm{ha}^{-1}\right)$. The results clearly establish the superiority of STCR approach for a target yield than other recommendations.

\section{CONCLUSION}

As finger millet is grown under low fertility soil with poor management, fertilization plays a greater role on productivity of the crop. The level, time and method of nutrient application are important. Balanced fertilization helps in realizing maximum yield of finger millet. Besides macro-nutrients, application of $\mathrm{ZnSO}_{4}$ and $\mathrm{FeSO}_{4}$ through foliage enhance productivity if the soil if deficient in these micro-nutrients. Organic manures, biofertilizers and INM play a greater role in boosting yield of finger millet with improvement of soil health. Further, legume based cropping system approach in nutrient management in finger millet plays pivotal role. The limitations in nutrient management studies in finger millet are: improvement of soil health for sustainable production and lack of researches on INM, identification of efficient finger millet based cropping system and STCR based nutrient management for different agroclimatic zones.

\section{REFERENCES}

Agricultural Statistics as a Glance, 2017. Government of India, Ministry of Agriculture \& Farmers Welfare Department of Agriculture, Cooperation \& Farmers Welfare, Directorate of Economics and Statistics, www.agricoop.nic.in (last visited: 30.11.2019)

Ahiwale, P.H., Chavan, L.S. and Jagtap, D.N. 2011. Effect of establishment methods and nutrient management on yield attributes and yield of finger millet (Eleusine coracana G.), Advance Research Journal of Crop Improvement, 2(2): 247-250.

AICSMIP (All India Co-ordinated Small Millets Improvement Project). 2013. Annual Report, GKVK Campus, UAS, Bangalore, pp. AG 15-18.

Arulmozhiselvan, K., Elayarajan, M. and Sathya, S. 2013. Effect of long term fertilization and manuring on soil fertility, yield and uptake by finger millet on inceptisol, Madras Agric. J., 100: 490-494.

Basavaraj Naik, T., Kumar Naik, A.H. and Suresh Naik, K.P. 2017. Nutrient Management Practices for Organic Cultivation of Finger Millet (Eleusine coracana L.) Under Southern Transitional Zone of Karnataka, India, Int.J.Curr. Microbiol.App.Sci, 6(11): 3371-3376.

Brahmachari, K., Sarkar, S., Santra D.K. and Maitra, S. 2018. Millet for food and nutritional security in drought prone 
and red laterite region of eastern India. International Journal of Plant and Soil Science, 26(6): 01-07.

Bulbule, A.V., Gajbhiye, P.N. and Kumbhar, C.T. 2018. Response of Finger Millet (Eleusine coracana L.) Cultivated on Steep Hill Slopes to Foliar Nutrition. International Journal of Plant Sciences, 183-187, ISSN 0976-593X. Available at: http://www.i-scholar.in/index.php/Ijps/ article/view/169834, last accessed: 02 Dec. 2019.

Chandrakala, M., Srinivasamurthy C.A., Kumar, S. and Naveen, D.V. 2017. Effect of Application of Graded Level of Phosphorus to Finger Millet - Maize Cropping System in Soils of Different P Fertility, Int. J. Curr. Microbiol. App. Sci., 6(11): 265-280.

Chavan, I.B., Jagtap, D.N. and Mahadkar, U.V. 2018. Effect of different establishment techniques, levels and time of application of nitrogen on partitioning of dry matter in finger millet [Eleusine coracana (L.) Gaertn.], Fmg. E Mngmt., 3(2): 104-109.

Choudhary, S., Baghel, S.S., Upadhyay, A.K. and Singh, A. 2019. STCR-Based Manure and Fertilizers Application Effect on Performance of Rice and Chemical Properties of Vertisol, Int. J. Curr. Microbiol. App. Sci, 8(3): 2080-2086.

Gawade, M.B., Mahadkar, U.V. and Jagtap, D.N. 2013. Effects of organic manures, sources and levels of fertilizers on yield attributes and yield of finger millet (Eleusine coracana G.), International Journal of Agricultural Sciences, 9(2): 795-798.

Harika, J.V., Maitra, S., Shankar, T., Bera, M. and Manasa, P. 2019. Effect of Integrated Nutrient Management on Productivity, Nutrient Uptake and Economics of Finger Millet (Eleusine coracana L. Gaertn), International Journal of Agriculture, Environment and Biotechnology, 12(3): 273-279.

Hegde, B.R. and Gowda, L. 1996. Cropping systems and production technology for small millets in India. In: Proceedings of the First International Small Millets Workshop, Bangalore, India, 29 October-2 November, 1986; pp. 209-236.

Hemalatha, S. and Chellamuthu, S. 2013. Impacts of long term fertilization on soil nutritional quality under finger millet: Maize cropping sequence. J. Environ. Res. Dev. 7:1571-1576.

Jagadeesha, N., Reddy, V.C., Krishnamurthy, N. and Sheshadri, T. 2010. Effect of organic manures on productivity of finger millet and redgram inter cropping system under protective irrigation. International Journal of Agricultural Sciences, 6(2): 453-455.

Kejiya, P., Vajantha, B., Naidu, M.V.S. and Nagavani, A.V. 2019. Effect of Phosphatic Fertilizer and Biofertilizers on Yield and Quality of Finger Millet (Eleusine coracana L.), Int. J. Curr. Microbiol. App. Sci., 8(7): 846-852.

Kumara, O., Basagaraj Naik, T. and Palaiah, P. 2007. Effect of Weed Management Practices and Fertility Levels on Growth and Yield Parameters in Finger Millet, Karnataka J. Agric. Sci., 20(2): 230-233.

Maitra, S., Ghosh, D.C., Sounda, G. Jana, P.K. and Roy, D.K. 2000. Productivity, competition and economics of intercropping legumes in finger millet (Eleusine coracana) at different fertility levels. Indian Journal of Agricultural Sciences, 70(12): 824-828.

Maitra, S., Roy, D.K., Mandal, B.K., Saeren, B.K., Ghosh, T.K. and Roy, A. 1997. Effect of different nutrients and other agronomic management practices on growth and yield of finger millet in sub-tropical humid region of West Bengal. Environment and Ecology, 15(2): 263-268.

Pallavi, Ch., Joseph, B., Aariff Khan, M.A. and Hemalatha, S. 2016a. Effect of integrated nutrient management on nutrient uptake, soil available nutrients and productivity of rainfed finger millet, International Journal of Science, Environment, 5(5): 2798-2813.

Pallavi, Ch., Joseph, B., Aariff Khan, M.A. and Hemalatha, S., 2016b. Economic Evaluation of Finger Millet under different Nutrient Management Practices, Int. J. Curr. Microbiol. App. Sci., 5(8): 690-698.

Patil, S.V., Bhosale, A.S. and Khambal, P.D. 2015. Effect of Various Levels of Fertilizers on Growth and Yield of Finger Millet, IOSR Journal of Agriculture and Veterinary Science, 8(6):49-52.

Pavankumar, G., Ramachandrappa, B.K. and Thimmegowda MN, 2016, Influence of rotation, use of organic and inorganic sources of nutrients on yield, nutrient uptake and economics of finger millet (Eleusine coracana (L.) Gaertn), Ecology, Environment and Conservation, 22: 39-46.

Prabhakar, Prabhu C. Ganiger, Boraiah B., Sujata Bhat, Nandini C., Kiran, Tippeswamy V. and Manjunath, H.A. 2017. Improved Production Technologies for Finger Millet, Project Coordinating Unit ICAR-AICRP on Small Millets GKVK, Bengaluru - 560 06, pp. 10-12.

Ramachandrappa, B.K., Sathish, A., Dhanapal, G.N., Ganapathi, Balakrishna Reddy, P.C., Shankar, M.A. and Srikanth Babu, P.N. 2013. Response of Rainfed Finger Millet to Levels and Time of Application of Potassium in Alfisols of Karnataka, Mysore J. Agric. Sci., 47(4) : 693-700.

Ramakrishnan, K. and Bhuvaneswari, G. 2014. Effect of inoculation of am fungi and beneficial microorganisms on growth and nutrient uptake of Eleusine coracana (L.) Gaertn. (Finger millet), International Letters of Natural Sciences, 13: 59-69.

Ramamoorthy, B., Narsimham, R.L. and Dinesh, R.S. 1967. Fertilizer application for specific yield targets of Sonara-64. Indian Farming, 17: 43-45.

Ramamoorthy, K. and Lourduraj, A.C. 2002. Integrated nutrient management in direct sown rainfed finger millet (Eleusine coracana Gaertn.), Madras Agric. J., 89(1-3): 33-35.

Rangaswamy, P. 1973. Effect of nitrogen and farm yard manure on finger millet Eleusine coracana (L) Gaertn. Madras Agricultural Journal, 60(8): 949-952.

Regar, K.L. and Singh, Y.V. 2014. Fertilizer recommendation based on soil testing for the targeted yield of rice in eastern plain zone of Uttar Pradesh. The Bioscan, 9(2): 531-534.

Reddy, B.H., Bulbule, A.V, Gajbhiye, P.N. and Patil, D.S. 2018. Effect of Foliar Application of Plant Nutrients on Growth and Yield of Finger Millet, Int. J. Curr. Microbiol. App. Sci., 7(3): 2203-2209. 
Roy, A.K., N. Ali, R.K. Lakra, P. Alam, P. Mahapatra and Narayan, R. 2018. Effect of Integrated Nutrient Management Practices on Nutrient Uptake, Yield of Finger Millet (Eleusine coracana L. Gaertn.) and PostHarvest Nutrient Availability under Rainfed Condition of Jharkhand. Int. J. Curr. Microbiol. App. Sci., 7(8): 339-347.

Roy, D. K., Chakraborty, T., Sounda, G. and Maitra, S. 2002. Growth and yield attributes of finger millet as influenced by plant population and different levels of nitrogen and phosphorus. Indian Agriculturist, 46(1-2): 65-71.

Roy, D.K., Maitra, S., Saren, A.K. Chakraborty, A. and Chakraborty, P. K. 1996. Response of finger millet varieties to levels of nitrogen under rainfed red and laterite zone of West Bengal, Environment and Ecology, 14 (2):367-370.

Sakamma, S., Umesh, K.B., Girish, M.R., Ravi, S.C., Satishkumar, M. and Veerabhadrappa Bellundagi. 2018. Finger millet (Eleusine coracana L. Gaertn.) production system: Status, potential, constraints and implications for improving small farmer's welfare. Journal of Agricultural Science, 10(1): 162-17.

Sandhya Rani, Y., Triveni, U., Patro, T.S.S.K. and Anuradha, N., 2017a. Effect of nutrient management on yield and quality of finger millet (Eleusine coracana (L.) Gaertn), International Journal of Chemical Studies, 5(6): 1211-1216.

Sandhya Rani, Y., Triveni, U., Patro, T.S.S.K., Divya, M. and Anuradha, N. 2017b. Revisiting of Fertilizer Doses in Finger Millet [Eleusine coracana (L.) Garten.] Through Targeted Yield and Soil Test Crop Response (STCR) Approach, Int. J. Curr. Microbiol. App. Sci., 6(7): 2211-2221.

Saraswathi, Shetty V. and Dinesh Kumar M. 2018. Effect of NPK application through different approaches on yield and secondary nutrient uptake by finger millet under rainfed conditions, Int. J. Pure App Biosci., 6(2): 735-741.
Sathish, A., Ramachandrappa, B.K., Shankar, M.A., Srikanth Babu, P.N., Srinivasarao, CH. and Sharma, K.L. 2016. Long-term effects of organic manure and manufactured fertilizer additions on soil quality and sustainable productivity of finger millet under a finger milletgroundnut cropping system in southern India, Soil Use and Management, 32(3): 311-321.

Srinivasarao, C., Venkateswarlu, B., Rattan Lal, Singh, A.K., Kundu, S, Pandu Ranga Vittal, K., Ramachandrappa, B.K. and Gajanane, G.N. 2012. Long-term effects of crop residues and fertility management on carbon sequestration and agronomic productivity of groundnutfinger millet rotation on an Alfisol in southern India, International Journal of Agricultural Sustainability, 10(3): 230-244.

Sundaresh, R. and Basavaraja, P.K. 2017. Influence of Different Levels of Phosphorus and Potassium on Growth, Yield Attributes and Economics of Finger Millet in Low Phosphorus and Potassium Soils of Eastern Dry Zone of Karnataka, India, Int. J. Curr. Microbiol. App. Sci., 6(11): 3559-3566.

Troug, E. 1960. Fifty years of soil testing. Transactions of 7th International Congress of Soil Science, Vol. 3, Commission IV, Paper No. 7, 46-53.

Vamshi Krishna, K., Deepthi, CH., Devender Reddy, M., Raju, P.S. and Pal, A. 2019. Effect of nitrogen and phosphorus levels on growth and yield of finger millet (Eleucine coracana L. Gaertn) during summer. Indian Journal of Agricultural Research (online edition, source: arccjournals. com, Article Id: A5317, last visited: 30.11.2019).

Yadav Rashmi, Malik N. and Yadav V. K., 2010. Response of finger millet (Eleucine coracana L. Gaertn) genotypes to nitrogen under rainfed situations of western Himalayan hills, International Journal of Agricultural Sciences, 6(1): 325-326. 
